\title{
A LABIAL ART-POLITICS
}

\author{
Hollie MacKenZie
}

SCHOOL OF POLITICS AND INTERNATIONAL RELATIONS, UNIVERSITY OF KENT

IAIN MACKENZIE

SCHOOL OF POLITICS AND INTERNATIONAL RELATIONS, UNIVERSTTY OF KENT

\begin{abstract}
In this article we focus on the potential for an alignment of certain feminist artistic practices and poststructuralist conceptions of critique that may enable ways of theorising practices of resistance and engender ways of practicing resistance in theory, without the lurch back into masculinist forms of dogmatism. It will be claimed that an ontological conception of art, considered as that which makes a difference in the world, can not only challenge the primacy of the dogmatic and masculine 'subject who judges', but also instil ways of thinking about, and ways of enacting, feminist artistic encounters with the capacity to resist dogmatism. The theoretical stakes of this claim are elaborated through complimentary readings of Deleuze and Guattari's constructivist account of philosophy and Irigaray's feminist explorations of what it means to think from within the 'labial', rather than from the position of the dominant phallic symbolic order. We argue that this creative conjunction between Irigaray, Deleuze and Guattari provides the resources for a conceptualisation of both feminist artistic practice and the critical practice of poststructuralist philosophy as forms of resistance to the dominant patriarchal order, in ways that can avoid the collapse back into masculinist forms of dogmatism. Revel's discussion of the role of constituent rather than constituted forms of resistance is employed to draw out the implications of this position for contentious politics. It is concluded that constituent practices of resistance can be understood as a challenge to the phallogocentric symbolic order to the extent that they are practices of a labial art-politics.
\end{abstract}

\section{Keywords}

Irigaray; Deleuze; art; politics

Corresponding author:

Iain MacKenzie, Email: i.mackenzie@kent.ac.uk 
$T_{1}$ he relationship between politics and art is a perennial theme in the history of Western thought but one that has assumed a new urgency in recent years (Ranciere, 2004; Alliez and Osborne, 2013; McLagan and McKee, 2013). One reason for this is that while standard accounts of this relationship have tended to presume definitions of art that prioritize the conditions of subjective judgement (building upon the ideas of Kant, 1952), recent work in continental aesthetics has shifted the terms of the discussion by arguing instead that art can and should be defined ontologically; such that art is not a judgement on the sensible but an encounter with the new (Cazeaux, 2000, for an overview). Suspicious that the emphasis upon subjective judgement may play into the hands of dominant economic, social, cultural and political forces, not least by virtue of privileging a gendered concept of subjectivity that can all too easily be aligned with the interests of patriarchy and capitalism, it has been claimed that art has the capacity to transform the given, including ideas of subjectivity and judgement, and that, therefore, it may constitute, in itself, a practice of resistance to those dominant structures (in different ways, Deleuze and Guattari, 1994; Ranciere, 2004). There is no doubt that this deep ontological alignment of art and politics engenders new ways of thinking about the creative dimensions of practices of resistance (McLagan and McKee, 2013). However, it is not entirely obvious that it overcomes the problem of how to avoid these practices of resistance becoming appropriated by the dominant order. As Maria Hynes (2013) explains:

When we speak of creativity we refer not just to the creation of something, but the creation of something that has value and no doubt we are left with a challenge of creating something with value when that value is so readily incorporated within the given - given modes of production and consumption, clichéd ways of thinking and being and so on (4).

In the discussion that follows we will focus on the potential for an alignment of certain feminist artistic practices and poststructuralist conceptions of critique that may enable ways of theorising practices of resistance and engender ways of practising resistance in theory, without the lurch back into cliché. In particular, we will address the question of how to avoid feminist and poststructuralist thought and practice becoming subsumed within, what Gilles Deleuze called, 'the dogmatic image of thought' (Deleuze, 1994). Articulating an ontological conception of art, considered as an encounter with the new, can not only challenge the primacy of the dogmatic and masculine 'subject who judges', but also instil ways of thinking about, and ways of enacting, feminist practices with the capacity to resist dogmatism. On the one hand, the difference that art makes can be understood as an expression of pure critique (MacKenzie, 2004) developed from within Deleuze and Guattari's (1991) constructivist account of philosophy as 'the creation of concepts'. Allied to this is the emancipation of artistic expression from political ends, on the basis of an understanding of the relationship between art and (political) philosophy that treats them as equally creative disciplines (Deleuze and Guattari, 1991). On the other hand, in order to explore the ways in which artistic practices can be sustained as a form of feminist resistance, it is necessary to consider what it means to think from within the labial, rather than from the position of the dominant phallic symbolic order. By expressing it in these terms, we invoke the work of Luce Irigaray (1985a, 1985b, 1985c, 1989, 1993a, 1993b) as it has been exemplary in its exploration of the potential for labial forms of expression. This conjunction between Irigaray, Deleuze and Guattari provides the resources for a conceptualisation of both feminist artistic practice and the critical practice of poststructuralist philosophy as forms of resitance to the dominant patriarchal order, in ways that can avoid the collapse back into cliché. The work of Judith Revel (2008) on the role of constituent rather than constituted forms of resistance will be used to further draw 
out the implications of this position for contentious politics. It will be concluded that constituent practices of resistance can be understood as a challenge to the phallogocentric symbolic order to the extent that they are practices of a labial art-politics.

\section{Becoming-woman}

In forging a link between feminist artistic practice and poststructuralist ideas of critique it is necessary to situate ourselves briefly within the now well-established literature on feminist interpretations of Deleuze and Guattari's singly and co-authored works (for an excellent overview of, and contribution to this literature see the essays collected in Buchanan and Colebrook, 2000). Typically this litertaure has focussed on the idea of 'becoming-woman' that they outline in $A$ Thousand Plateaus (1987). In this section, therefore we will address this notion by situating it briefly within, in the first instance, a broader understanding of Deleuze's philosophical project before then turning to a discussion of how it can be understood as complimentary to Irigaray's feminist philosophy, and how Irigaray's feminist politics can be read as contributing to Deleuze's (and Guattari's) philosophy of difference.

Deleuze's philosophy is based on a metaphysics of pure difference that critiques and challenges all philosophies of representation (Deleuze, 1994). Instead of presuming that philosophy must be aimed at representing in thought some aspect of the world (or Self, or God, etc), he argues that philosophy should be understood as the expression of ideas (Deleuze, 1994, especially chapters 3 and 4). For Deleuze, an idea is not a mental solution to a worldly problem; rather, an idea is a structure in the world, virtual but nonetheless real, that expresses a problem (Deleuze, 1968, 156-67). This can be more fully articulated with reference to Deleuze's way of embracing the structuralist challenge to humanism without reifying the concept of structure itself (Deleuze, 2004). Where structuralists tended to replace the centrality of humanity with the centrality of structure when it came to grounding knowledge claims, Deleuze follows the poststructuralist route by arguing a) that all the relations that make up structures are differential relations and b) that there exists a difference between the structure and its expression in actual states of affairs. As he puts it, structure 'is differential in itself, and differentiating in its effect' (Deleuze, 2004, 180). Taken together, it is not possible to identify unchanging structures (given the differences that constitute them), nor to explain phenomena as a simple effect of deep-seated structures. In both respects, the structured ideas that condition experience are intrinsically problematic. The upshot is that there is an art to writing within, rather than about, the structures that condition our experience, and that this can be usefully thought of as learning the art of expressing ideas as problems. As we will see, indeed, this art is central to Deleuze's challenge to dogmatic modes of thought and being in the world.

Although there are significant philosophical issues that are still being worked on with regard to Deleuze's debt to structuralism (Bowden, 2011; Dosse, 1997, for some important background material), it is widely understood that he viewed the art of expressing ideas as itself conditioned by encounters (Deleuze, 1994). In order to engage with the ideas that structure our experience Deleuze maintained that we must be open to an encounter with them. While this may be read as a gesture that prioritizes a certain passivity, it is better understood as the practical activity of unmasking the will to know behind every dogmatism (Cutler and MacKenzie, 2011). In Difference and Repetition, he argues that the will to know is the most fundamental assumption of the dogmatic image of thought and that the practical activity of critique must eschew knowledge-claims in favour of the instantiation of a culture of learning. As Deleuze puts it; '[i]t is from learning, not from knowledge that the transcendental conditions of thought must be drawn' (Deleuze, 1968, 166). Moreover, to 
the extent that learning is the practical critique of all dogmatism (Cutler and MacKenzie, 2011), it serves to dethrone the image of the masculine subjectivity sitting in sovereign judgement over experience (Braidotti, 1994, Olkowski, 2000). In this context, therefore, we would suggest that becoming-woman can be read in a very specific sense: as the practical task of learning to critique masculine forms of thought and subjectivity embedded in language, culture and the psyche. It is not, therefore, a claim that rests on 'knowing' the nature of woman, or claiming that there is one. Quite the opposite, it is a way of articulating the critical task of dethroning all masculinist presumptions based upon the priority of the will to know. But given that Deleuze and Guattari did not develop this critique of phallogocentrism (in the way that Derrida, who coined the term, did - albeit with different poststructuralist resources) it is useful at this point to link becomingwoman to Irigaray's more explicitly feminist philosophical project.

As Irigaray states: 'If language does not give both sexes equivalent opportunities to speak and increase their self-esteem, it functions as a means of enabling one sex to subjugate the other' (Irigaray, 1989, xv). It is not only that women have been physically and symbolically dispossessed, women have been physically and symbolically subjugated. Irigaray explains that the social form specific to women needs to be transformed: rather than percieving women as the 'Other'/'the Second Sex'/'the Sex That is Not One' through the 'commercial use of their bodies and images', they should instead introduce 'valid representations of themselves in actions, words, and images in all public spaces' (Irigaray, 1993, 86). She criticises the ways in which women's difference has always in practice been used against them and the ways in which dominant social forces tend 'to portray men as respectable citizens, as civil and religious authority figures, and consider women to be sexual property at the disposal of men' (Irigaray, 1989, xvi). Thus, women need social status within patriarchy in order to develop their own interests and rights; to become-women. Irigaray (1989) says:

My purpose in demanding these rights for women is to make them take responsibility for themselves socially, make them responsible adult citizens. It is up to them to protect their virginity, their motherhood, their bit of nature, their house, their images, languages, $\operatorname{god}(\mathrm{s})$ or goddess(es). It is therefore up to them to become subjects capable of sublimating their sexual drives, cultivating their sexuality, giving it rhythm, temporality, stakes. To do this women need rights (81).

These are, as Irigaray notes, rights to human dignity, identity, motherhood, systems of exchange and representation in equal numbers. Once these rights have been achieved, the next rights in the list will also follow, consisting of the legal encodification of rape, forced prostitution and pornography, a right to defend their own and their children's lives, a right to equivalent exchange for men and women, and equal representation in civil and religious decision-making bodies (Irigaray, 1993, 86-9). According to Irigaray, these rights are different from the rights women have in liberal democracies, because the maximum individual liberty acheivable by women in a liberal democratic state would still mean that they remain subordinate to the idea of Man. Once women are therefore emancipated from their subjugated position, they will thus be on an equal level playing field together with, and alongside, men. Braidotti gives a useful gloss on these ideas when, invoking Deleuze and Guattari, she states that this 'entails the problematics of how to emancipate 'woman' from the subjugated position of annexed 'other', in order to make her expressive of a different difference, of pure difference, of an entirely new plane of becoming, out of which differences can multiply and differ from each other' (Braidotti, 1994, 115). In this respect, Braidotti is correct to draw out a deep connection between Irigaray's explicity feminist 
project and Deleuze and Guattari's philosophy of difference that led them to the idea of becomingwoman; a connection also articulated by Olkowski (2000) and Lorraine (1999).

However, as Braidotti (1994) also highlights:

one cannot deconstruct a subjectivity one has never controlled. Self-determination is the first step of any program of deconstruction. I concluded that Deleuze gets caught in the contradiction of postulating a general "becoming-woman" that fails to take into account the historical and epistemological specificity of the female feminist standpoint. A theory of difference that fails to take into account sexual difference leaves me as a feminist critic in a state of skeptical perplexity (117).

Braidotti's 'conclusion' would seem to undermine the conjunction of Deleuze and Irigaray that we are presenting as central to a labial art-politics. As Lorraine (1999) explains, however, this need not be the case. For Lorraine, 'Deleuze's philosophical project will turn out to foster the becoming-imperceptible of a nomadic subject' (137). By emphasising the 'becoming-imperceptible of a nomadic subject', Lorraine captures an important aspect of Deleuze and Guattari's project that is not foregrounded by Braidotti; namely, the dynamic between the molar and the molecular dimensions of identity in Deleuze and Guattari's account. In Braidotti's criticism of Deleuze and Guattari this dynamic is missing, at least to the extent that she reads becoming-woman as too 'general' to enable 'the historical and epistmological specificity of the female feminist standpoint' she takes as central to feminist critique. The dynamism that Lorraine invokes, provides the grounds for the imperceptible becoming of women that precisley enables the feminist standpoint Braidotti envisages. Indeed, as Braidotti explains, 'women must speak the feminine-they must think it, write it, and represent it in their own terms' (1994, 117). Feminists must not only critique phallogocentric power in/as discourse, but create other ways of thinking that are different to the dogmatic and phallogocentric image of thought they are criticising. As Olkowski puts it; '...if we succeed in depathologising everything associated with women by constituting a logic and language of fluidity, all those words that are so distatseful because they express the body of woman - the uteral, the vulvar, the clitoral, the vaginal, the placental, or woman's luminous body itself - may then enter, for the first time ever, into our knowledge' (107). Engaging in this process of depathologisation, we argue, is precisely the practical activity of learning to think differently, not to eliminate female sexual identity and subjectivity, but to aid in the pursuit of finding new and different ways of thinking about, and being in, the world.

In this context, it is useful to consider Whitford's (1991) suggestion that we may need to assess the way in which we read Irigaray's work in order to adjust our effort of understanding, insisting on the time of understanding; and how this time could be a slow process of making connections (1991, 5). Faced with working at the limits of masculine syntax, grammar etc, as well as conceptualisation, feminists have sought to bring woman into existence by exploring practices of writing. Perhaps it's about linking together the ideas of learning, time and understanding, more explicitly and more generally, as an artistic practice aimed at the exploration of what it is to become a woman. In this way, it may be that 'all those distasteful words' (Olkowski, above) may not only enter into our knowledge but that 'all those distasteful feminine forms' may enter into the distribution of the sensible (Ranciere, 2004) in ways that engender practices of resistance that include but are not limited to writing aimed at the exploration of what it is to become a woman. In this way, adjusting our time of understanding creates opportunities for the exploration of becomingwoman through multiple practices of learning.

Inhabiting this time engenders a new conceptualisation of feminine safe space, that would 
enable women to investigate forms of feminine expression free from the 'hysteric' restraints of the phallic signifier. As Irigaray suggests, however, once feminine symbolic and linguistic structures can co-exist with the dominant masculine structures both sexes will have gained a location from which they can speak, such that they can collectively critique phallogocentrism. Becoming-woman may be a minoritarian politics (Deleuze and Guattari, 1987) but it is also irreducibly a common politics.

\section{A Common Politics}

Recognising that this account of the importance of becoming-woman may not resonate with commonly held assumptions about practices of resistance and contentious politics, this section will elaborate upon the connection between notions of nomadism in Deleuze and Guattari and the labial in Irigaray to draw out a parallel to the idea of constituent process of resistance, as theorised by Judith Revel (2008).

Discussing the etymology of 'nomadism', Deleuze and Guattari (1987) explore the Greek words nem, which means 'to distribute', and nemô, which translates as 'pasture livestock'. Combined, the origins of the term nomadism imply unguided animals let out to an unbounded pasture without any attempt to structure or pattern their movements (Deleuze and Guattari, 1987, 380). Therefore, within the space of the nomos, movement is primary and non-hierarchal. They contrast this understanding of the nomos with another Greek word, logos (1987, 369-73). Logos is usually understood to mean 'law' and is used to depict a world that is well-ordered and structured. In this context, the 'smooth space' of the nomos is directly analagous to the 'labial' space Irigaray unfolds and which serves as basis for the critique of the well-ordered, rigid and static patriarchal logos of social formations (1985a and Olkowski, 2000). But in what sense exactly?

In order to create this 'smooth space', according to Deleuze and Guattari, we must destratify the territories of representation and the will to know, in order to learn to think differently. While every deterritorialisation is accompanied by a reterritorialization there is nonetheless a process of critique embedded in the transformation from one territory to another that is the becomingimperceptible of women becoming-women, a process that 'occurs' on the smooth labial space of pure difference. It is the dynamic between the smooth and the striated that is important; we must remember that labias are folded not simply smooth and that penises are just folds too, of course, but culturally striated in the symbolic world as the phallic. Labias are different, however, in that their folds have no centre, they are different in and of themselves, expressing a continuous differential enactment of singularities. The 'two lips' of the labia are in fact 'neither one nor two' and this 'keeps woman in touch with herself, but without any possibility of distinguishing what is touching from what is touched' (Irigaray, 1985a, 32). Therefore, in contrast to phallic forms of thought, labial forms offer a non-dogmatic, non-judgemental basis for thinking the relationship between the represented and representation and for thinking the possibility of pure critique as the practice of learning. On this basis, part of what a labial art-politics promises is an ongoing, never complete, ever-folding, learning, to come.

This can be usefully developed in relation to a key distinction that Judith Revel (2008) brings into play when discussing how we should rethink resistance. She argues that resistance must be thought of within time as well as within history: 'give it the chance to not only experiment with new strategies of resistance, invest new fields, and try to produce new modes of life, but also to accumulate and sediment the results thus achieved, the conflicts built, the subjectivities set into motion. In order to do this we absolutely need to think of the constituent dimension of resistance (its asymmetry) as well as a constituted one'. This suggestion can be read back to the 
transcendental priority of learning over knowledge. Revel recognises the consequences of this proposal: she concludes that 'the institutions at the heart of constituent processes can be nothing but institutions of the common' as the 'processes of subjectivation always simultaneously invest a relationship to the self and a relationship to others, taking the form of an experimentation with shared modes of life (the creation of languages, exchanges, affects, relations, pedagogy, desire, pleasure etc.)'.

Revel's notion of the 'common' resonates with Deleuze's notion of the nomad's 'smooth space', as well as Irigaray's discussion of the multiple folds of the labia. Interpreting Revel's invocation of the 'common' alongside Deleuze's notion of smooth space expresses the unguided and unstructured movement of people that challenges the striated symbolic order. However, to what extent should Revel's invocation of the common be read as an appeal to community action and, if so, does it sit happily alongside a Deleuze/Irigaray conception of becomingwoman? One the one hand, and as with Deleuze's poststructuralist account of structure, we propose that Revel does not reify commonality but rather emphasises the role of differential bonds between the people that make up the common, and the multiple constituencies that can express these differential bonds. On the other hand, a fruitful way of approaching this issue from an Irigarayian perspective is through Boothroyd's (1996) interpretation of Irigaray. According to Boothroyd, Irigaray's focus on “"cultural detumescence” $(1996,67)$ and becoming could create the basis for a project of radical democracy which would consist of a common construction of singularities which could promise 'a non-nihilistic ethical future for both women and men' (Boothroyd, 1996, 77). Together these both suggest the consonance of reading Revel's idea of the common alongside Irigaray and Deleuze and Guattari. In the next section we explore how this possibility is expressed through lines of flight understood as artistic encounters.

\section{Lines of Flight as Artistic Encounters}

In this section we claim that the constituencies of resistance correctly identified by Revel as necessary for the construction of common cause are created through lines of flight understood as processes that engender artistic encounters with labial forms. Deleuze and Guattari (1987) explain that lines of flight 'never consist in running away from the world but rather in causing runoffs' (204). What they mean by this is that a line of flight should not be understood as an act of escape, but as the practices that enable the critique of dominant systems of thought and social conditions from within the processes that maintain their reproduction (Deuchars, 2010, 4). Thus, the line of flight only makes sense with a presumption that the reproduction of dominant social assemblages (to use their concept) always already contains within it the potential for a productive disruption of that dominance. For example, these lines of flight involve deconstructing our oedipal identity in the name of becoming-woman. As Deleuze and Guattari say, 'She is an abstract line, or a line of flight' $(1987,305)$. In this sense, 'she' is a 'runoff' from the dominant phallic order capable of pursuing the impeceptible becomings of a smooth labial space, as a feminist resistance.

How can we then create a line of flight/difference in thought whilst we are still stuck and limited to dominant phallogocentric systems of thought? It is useful to return to Revel (2008) and her notion of resistance as production: 'resistance needs to be given as an asymmetry, that is to say affirmative of its positive and propositive dimension - in one word productive - in order to speak of its creative difference and its ability to invent new being (new forms of life, new modes of subjectivation)'. In the terms we have been elaborating above, a line of flight is an act of creation understood as a fundamental encounter which 'forces us to think'. Deleuze describes this encounter as 'an object not of recognition ... What is encountered may be Socrates, a temple 
or a demon. It may be grasped in a range of affective tones: wonder, love, hatred, suffering. In whichever tone, its primary characteristic is that it can only be sensed' (Deleuze, 1994, 139). It is this sensual characteristic that is characteristic of works of art; every day experience dulls the senses whereas art has the capacity to enliven them. A productive act of resistance, therefore, requires an artistic encounter with the new and artistic production has the capacity to produce practices of resistance. However, in thinking about the relationship between art and politics in this way there is still the lingering question posed by Hynes; can creative forms of resistance be thought and practiced in ways that avoid their recuperation within the dominant symbolic order?

Having already established that a feminist practice of resistance as an artistic practice could provide the most fruitful and creative way to resist, rupture and become, the same thought can also be applied to this dilemma. According to Hynes (2013b), 'with its potentiality for processual immanence, the aesthetic paradigm mobilises life as well as a vital yet material force of generativity'. She further explains the implications of this paradigm for conceptualisations of resistance arguing that 'it opens the way toward an ontology of resistance that recognises the priority of resistance with respect to power; namely, that, far from being the parenthetic margin of freedom that one exercises in the face of power, resistance is that creative becoming upon which power is parasitic' (Hynes, 2013b). An artistic feminist practice of resistance, in these terms, provides a useful way of conceptualising the expressive art of problematisation and learning as a practice of critique that compliments Revel's account of the necessary productivity of constituent resistance in the face of the static rigid phallogocentric power structures that dominate the psyche as well as the social, economic and political domains.

Nonetheless, it is still important to clarify the ontological account of art as a basis for the practice of learning to become-woman. As discussed above, Deleuze considers the 'art object' to be not 'an object not of recognition but of a fundamental encounter' of which he further describes 'its primary characteristic is that it can only be sensed' (Deleuze, 1994, 139). As Simon O'Sullivan (2006) elaborates:

Art then is the name of the object of an encounter, but also the name of the encounter itself, and indeed of that which is produced by the encounter. Art is this complex event that brings about the possibility of something new (1-2).

Building upon this account, we claim that it is within art, understood as an affective encounter with the idea that it expresses (as discussed above), that we should look for the possibility of new 'labial' signifiers that can foster becoming-woman. It is through artistic encounters that we may situate the potential for a feminist artistic practice that engenders labial signifiers to challenge phallogocentrism. The artistic practice of transforming the way we experience the world, a practice of learning how to express the problems that reside within ideas, will also transform the way we engage with it. It is through artistic practice, that living as a (man and) woman on the edge of learning will enable (men and) women becoming-woman to find their constituent practices of resistance in common through the expression of their own singularity.

\section{Conclusion: A Labial Art-politics}

As Linda Nochlin (1975) puts it, women's art possesses a different kind of "greatness" to men's art; different both in its formal and its expressive qualities, the artwork conveys the special character of women's situation and experience. There is a quality to women's art that is, at least in part, the result of its capacity to express the conditions that make it necessary. Our argument 
is that women artists can become politically engaged in practices of resistance by making visible within their art these conditions understood as 'the meeting point of the properties of physical matter and an elaboration of sexualised subjective identity' (Irigaray, 1993, 153). But it is also that those engaged in contentious politics can learn how to resist by becoming-woman and becoming-artists. It is through such practices that the minoritarian and subjected condition of women can engender lines of flight from the dominant order. Importantly, though, these must be creative practices, through and through: 'Don't restrict yourself to describing, reproducing, and repeating what exists, but know how to invent or imagine what hasn't yet taken place' (Irigaray, 1993 , 49). To the extent that this can be acheived then that which is produced is not just an art work or form of protest, it is a new mode of life that contains within itself the conditions of its own sustainability. Art and political movements, understood in this way, become 'an event that actualises a set of virtualities and in so doing expresses a possible world' (O'Sullivan, 2006, 130). Accordingly, the value of creativity will never be subsumed within capitalist and patriarchal structures because these have been left behind in the creation of 'a possible world'.

Nonetheless, it is important to acknowledge that this utopian dimension of art and politics may appear to legitimate flights of fancy rather than becomings along a line of flight. This would indeed be the case if the 'possible worlds' were thought to be worlds above or beyond the world we find ourselves inhabiting. Rather, the utopian dimension of art and politics, when properly understood, resides in its capacity to intensify the present: 'art, then, has a particular receptivity to the future, enabling it to deploy the potential of the future into the present in order to intensify it' (Hynes, 2013a, 6). It is through such intensification that the artist can create new and different forms, objects and images to establish problematics and critiques which can challenge what is known, thought and symbolised. Equally, though, it is in the intensification of the present that the common politics becomes the art of finding new forms of life. The nature of an artistic (feminist and poststructuralist) practice of resistance capable of challenging the norms of capitalism and patriarchy can now be summarised; to live with the problem of learning how to become-woman, through art, in common. Within artistic encounters common processes and practices are produced that, if not overcoded with masculinist forms of dogmatism, amount to neither political art nor an aesthetic approach within political theory; rather, an enfolded practice of art and politics 'without any way of distinguishing what is touching from what is touched'; a labial art-politics. 


\section{References}

Alliez, E. and Osborne, P. (2013) Eds. Spheres of Action: Art and Politics. London: Tate.

Boothroyd, D. (1996). 'Labial Feminism: Body Against Body with Luce Irigaray,' in Paradox issue 3, 361-86.

Bowden, S. (2011). The Priority of Events: Deleure's Logic of Sense. Edinburgh: Edinburgh University Press.

Braidotti, R. (1994). Nomadic Subjects: Embodiment and Sexual Difference in Contemporary Feminist Theory. New York: Columbia University Press.

Buchanan, I. and Colebrook, C. (2000) Eds. Deleuze and Feminist Theory. Edinburgh: Edinburgh University Press.

Cazeaux, C. (2000). The Continental Aesthetics Reader, $2^{\text {nd }}$ edition. London: Routledge.

Cutler, A. and MacKenzie, I. (2011). 'Bodies of Learning' in Guillaume, L. and Hughes, J. Eds. Deleuze and the Body. Edinburgh: Edinburgh University Press.

De Beauvoir, S. (1949). The Second Sex. Paris: Editions Gallimard.

Deleuze, G. (1994). Difference and Repetition. London: The Athlone Press.

Deleuze, G. (2004). Desert Islands and other texts, 1953-1974. New York: Semiotext(e).

Deleuze, G. and Guattari, F. (1987). A Thousand Plateaus: Capitalism and Schizophrenia. Minneapolis: University of Minnesota Press.

Deleuze, G and Guattari, F. (1994). What Is Philosophy? London and New York: Verso.

Deuchars, R. (2010). 'Creating Lines of Flight and Activating Resistance: Deleuze and Guattari's War Machine'. Philosophy and Culture, 2010, http: / / www.philosophyandculture.org/ books/2010/humanbeings07.pdf (accessed June 19, 2013).

Dosse, F. (1997). History of Structuralism, vol 2: the Sign Sets, 1967-Present. Minneapolis: University of Minnesota Press.

Guattari, F. (1995). Chaosmosis - An Ethico-Aesthetic Paradigm. Bloomington/Indianapolis: Indiana University Press.

Hynes, M. (2013a). 'Affirming Creativity: Playing with Concepts', paper delivered at Goldsmiths, http:/ / www.gold.ac.uk/media/Hynes.pdf (accessed May 20).

Hynes, M. (2013b). 'Creative Life and the Sensation of Resistance', paper delivered at University of Kent, July 1-2.
Kant, I. (1952). The Critique of Judgement. Oxford: Clarendon Press.

Irigaray, L. (1985a). This Sex Which is Not One. New York: Cornell University Press.

Irigaray, L. (1985b). 'Is the Subject of Science Sexed?', in Cultural Critique, Issue 1, Fall, 73-88.

Irigaray, L. (1985c). Speculum of the Other Woman. New York: Cornell University Press.

Irigaray, L. (1993a). Je, Tu, Nous: Towards a Culture of Difference. London and New York: Routledge.

Irigaray, L. (1993b). Sexes and Genealogies. New York: Columbia University Press.

Irigaray, L. (1994). Thinking the Difference: For a Peaceful Revolution. London: The Athlone Press.

Lorraine, T. (1999). Irigaray \& Deleuze: Experiments in Visceral Philosophy. New York: Cornell University Press.

MacKenzie, I. (2004). The Idea of Pure Critique. London: Continuum.

McLagan, M. and McKee, Y. (2013) Eds. Sensible Politics: The Visual Culture of Nongovernmental Activism. New York: Zone Books.

Nochlin, L. (1975). Women, Art, and Power and Other Essays. Boulder: Westview Press.

Olkowski, D. (2000). 'Body, Knowledge and becoming-Woman: Morpho-logic in Deleuze and Irigaray' in Buchanan, I. and Colebrook, C. Eds. Deleuze and Feminist Theory. Edinburgh: Edinburgh University Press, 86-109.

O'Sullivan, S. (2006). Art Encounters Deleuze and Guattari: Thought Beyond Representation. Hampshire and New York: Palgrave Macmillan.

Rancière, J. (2004). The Politics of Aesthetics. London: Continuum.

Revel, J. "Resistances, subjectivities, common." Generation-online, 2008. http://www. generation-online.org/p/fprevel4.htm (accessed June 18, 2013, page numbers not available).

Robinson, H. (2006). Reading Art, Reading Irigaray: The Politics of Art by Women. London and New York: I.B.Tauris.

Whitford, M. (1991). Luce Irigaray: Philosophy in the Feminine. London and New York: Routledge. 